\title{
CELL PROLIFERATION ASSAY - METHOD OPTIMISATION FOR IN VIVO LABELING OF DNA IN THE RAT FORESTOMACH
}

\author{
JOKSIĆ Gordana ${ }^{1 *}$, MIĆIĆ Mileva ${ }^{2}$, FILIPOVIĆ Jelena ${ }^{1}$, DRAKULIĆ Dunja ${ }^{1}$, \\ STANOJLOVIĆ Milošํㅡㄹ ČALIJA Bojan ${ }^{3}$, VALENTA ŠOBOT Ana ${ }^{1}$, DEMAJO \\ Miroslav $^{1}$, NILSSON Robert ${ }^{1}$
}

${ }^{1}$ Vinča Institute of Nuclear Sciences, University of Belgrade, Mike Petrovica Alasa 12-14, 11001 Belgrade, Serbia; ${ }^{2}$ Institute for Medical Research, University of Belgrade, Dr. Subotića Street 4, 11129 Belgrade, Serbia; ${ }^{3}$ Faculty of Pharmacy, University of Belgrade, Vojvode Stepe 450, 11221 Belgrade, Serbia

(Received 30 June, Accepted 18 October 2016)

\begin{abstract}
The study of cell proliferation is a useful tool in the fields of toxicology, pathophysiology and pharmacology. Cell proliferation and its degree can be evaluated using 5-bromo-2'deoxyuridine which is incorporated into the newly synthesized DNA. The aim of this study was the optimization of subcutaneous application of 5-bromo-2'-deoxyuridine implantation for continuous and persistent marking of proliferating cells in the rat forestomach. 3-tert-Butyl-4-hydroxyanisole was used as the agent that ensures cell proliferation. In order to determine the optimal dose for proliferating cells labeling, 5-bromo-2'-deoxyuridine doses of $50 \mathrm{mg}, 100 \mathrm{mg}, 200 \mathrm{mg}$ or $350 \mathrm{mg}$ were implemented 2 days prior to sacrifice by flat-faced cylindrical matrices. Immunohistochemical analysis using 5-bromo-2'-deoxyuridine in situ detection kit was performed for the detection of 5-bromo-2'-deoxyuridine labeled cells. The results showed that for adult rats, the optimum 5-bromo-2'-deoxyuridine dose is $200 \mathrm{mg}$ per animal for subcutaneous application. The here described manner of 5-bromo-2'-deoxyuridine in vivo labeling provides a simple, efficient, and reliable method for cell labeling, and at the same minimizes stress to animals.
\end{abstract}

Key words: 5-bromo-2'-deoxyuridine, 3-tert-Butyl-4-hydroxyanisole, BrdU in vivo labeling; cell proliferation; rat forestomach

\section{INTRODUCTION}

The rat stomach is morphologically and physiologically different from the human and the stomach of other laboratory animals. Its proximal nonglandular part, i.e. the forestomach, constitutes approximately $60 \%$ of this organ and it consists of a stratified squamous epithelium which is constantly renewing [1]. Therefore, the balance between

\footnotetext{
*Corresponding author: e-mail: gjoksic@vinca.rs
} 
cell proliferation and cell loss by apoptosis is necessary for the normal functioning of the forestomach.

The main function of the forestomach is to serve as a food reservoir leading to longterm exposure to xenobiotics, which makes it a good target tissue in cell proliferation studies [2]. Numerous xenobiotics lead to disturbed tissue homeostasis, which may result in cell loss, consequent tissue atrophy and failure, or excessive cell proliferation and eventually carcinogenesis, which makes cell proliferation studies a very important and useful tool.

The forestomach is sensitive to tissue damage by non-genotoxic compounds like the food additive 3-tert-Butyl-4-hydroxyanisole (BHA). BHA is commonly used as an antioxidant food additive in fats and oils (E321). There is evidence that prolonged exposure to this agent induces hyperplasia that eventually results in carcinomas in the rat forestomach [3,4]. On basis of such data the International Agency for Research on Cancer (IARC) has classified BHA as a B2 carcinogen [5].

The study of cell proliferation is a useful tool in the fields of toxicology, pathophysiology and pharmacology [6,7]. Cell proliferation and its degree can be evaluated using 5-bromo-2'-deoxyuridine (BrdU) which is incorporated into the newly synthesized DNA, during the $\mathrm{S}$ phase of the cell cycle [8]. BrdU is a thymine analogue which pairs with purine bases with different affinity depending on its isoform, i.e. in the keto form it pairs with adenine, whereas in the enol form it pairs with guanine [9]. This method allows the quantification of newly generated cells and therefore enabled the study of the effects of xenobiotics on cell proliferation, death and migration behavior in a quantitative manner [10]. Pharmacokinetics studies showed that the most commonly used doses of BrdU (50-100 mg/ kg) and routes of administration such as intravenous and intraperitoneal (i.v. and i.p., respectively) are suitable for use in pulselabel experiments. BrdU is quickly degraded in vivo, and its half-life is approximately $60 \mathrm{~min}$ both in the blood serum and in various tissues [11,12]. For continuous-label studies a prolonged and continuous exposure to the labeling agent must be achieved.

Although several administration routes of BrdU have already been described in order to mark proliferating cells, accurate monitoring of proliferation in tissues that need more time for renewal requires further optimization. Furthermore, the effects of subacute or chronic exposure to proliferating agents could be observed more precisely with continuous-label methods. The aim of this study was to optimize a subcutaneous BrdU implantation for continuous and persistent marking of proliferating cells. As the agent that ensures cell proliferation we used 3-tert-Butyl-4-hydroxyanisole (BHA) [3].

\section{MATERIALS AND METHODS}

\section{Animals}

All procedures on animals were approved by the Ethical Committee for the Use of Laboratory Animals, University of Belgrade, Vinča Institute of Nuclear Sciences 
(Number of Ethical Committee approval DD1/15), according to the guidelines of the EU registered Serbian Laboratory Animal Science Association (SLASA).

Seven weeks old male Wistar rats $(250 \pm 10 \mathrm{~g})$, obtained from the local colony and separate litters, were maintained under standard conditions: group-housed (4 per cage) with free access to food (commercial pellet) and tap water, regular $12 \mathrm{~h}$ light $/ 12 \mathrm{~h}$ dark cycle and constant temperature $\left(21 \pm 2^{\circ} \mathrm{C}\right)$ and humidity.

\section{Treatment and surgical procedure}

The experimental design is presented in Table 1. On the first day of the experiment, animals were randomly divided into two main groups: (I) control animals; (II) rats intragastrically intubated (reusable stainless steel feeding needle, 16-G4", $3 \mathrm{~mm}$ ball diameter, Cadence Inc., Staunton, Virginia, USA), three times per week for 4 weeks with butylated hydroxyanisole (BHA) (2\% BHA in the powdered feed) (Sigma-Aldrich Co., Saint Louis, Missouri, USA). Although it has been reported that rat pellets may be enriched with BHA and the animals consume this food readily [3], animals refused to consume pellets prepared in this way, rapidly losing their body mass, thus forcing us to feed the animals by intubation a mixture of pellets with BHA. Additionally, two days prior to sacrifice animals were subdivided into experimental groups according to implemented BrdU doses: 50 mg, 100 mg, $200 \mathrm{mg}$ or $350 \mathrm{mg}$ ( $\mathrm{n}=4$ per experimental group). Animal weight at this point was $372 \pm 21 \mathrm{~g}$. Flat-faced cylindrical matrices containing $50 \mathrm{mg}$ of BrdU (Sigma-Aldrich Co., St. Louis, USA) with a diameter of $5.6 \mathrm{~mm}$ were prepared by a direct compression technique using an eccentric tablet press (Korsch EK-0, Korsch, Berlin, Germany). BrdU matrices were subcutaneously implanted in the dorsal neck region under 5\% chloral hydrate $(400 \mathrm{mg} / \mathrm{kg}$, SigmaAldrich Co., St. Louis, USA) anesthesia.

Table 1. Number of BrdU positive cells in the forestomach epithelium treated with different doses of BrdU.

\begin{tabular}{ccc}
\hline Groups & Doses of BrdU (mg) & Number of cells $/ \mathbf{m m}^{2}$ \\
\hline Control & 200 & $18.24 \pm 8.4$ \\
BHA & 50 & $16.95 \pm 6.1^{\mathrm{a}}$ \\
BHA & 100 & $51.07 \pm 25.0^{\mathrm{b}}$ \\
BHA & 200 & $67.63 \pm 21.5^{*}$ \\
BHA & 350 & $75.27 \pm 21.0^{*}$ \\
\hline
\end{tabular}

The results are represented as mean $\pm \mathrm{SD}$

${ }^{*} \mathrm{p}<0.001$ BHA treated vs. control animals; ${ }^{\mathrm{a}} \mathrm{p}<0.01$ BHA treated animals which received $50 \mathrm{mg}$ vs. animals which received 100, 200 and $350 \mathrm{mg} \mathrm{BrdU;}{ }^{\mathrm{b}} \mathrm{p}<0.01 \mathrm{BHA}$ treated animals which received $100 \mathrm{mg}$ BrdU vs. animals which received 200 and $350 \mathrm{mg}$ BrdU.

During post-operative recovery, physical health condition of all rats was closely monitored on a daily basis. 


\section{Tissue preparation}

The animals were sacrificed by decapitation, the stomachs removed, the forestomach separated, cut along the minor curvature, washed in $0.9 \%$ aqueous sodium chloride, spread on paraffin substrate with pins and covered with $10 \%$ neutral buffered formalin for one week. After fixation, the tissues were dehydrated in a series of ethanol solutions (70\%, 96\% and 100\%) and xylene, and then embedded into paraffin blocks. Paraffin tissue blocks of the forestomach were cut transversely into serial sections $5 \mu \mathrm{m}$ in thickness.

Two consecutive sections, with ten levels, ranging from $250 \mu \mathrm{m}$ between each level, were taken for: a) histochemical staining with hematoxylin and eosin for histological analysis and b) immunohistochemical staining for the detection of BrdU incorporation into DNA, i.e. analysis of cell proliferation. The analysis was done on light microscope Olympus AX70 with $10 \times$ and $20 \times$ objective magnification.

\section{Immunohistochemical procedure}

After deparaffinization in xylene, treatment with descending concentrations of alcohols, and rehydration in distilled water the forestomach sections were stained immunohistochemically according to the manufacturer's instructions (BrdU in situ detection kit, BD Pharmingen, New Jersey, USA). The procedure is based on the use of a directly biotinylated monoclonal antibody against BrdU, streptavidin-HRP solution as the detection system and 3,3'-diaminobenzidine (DAB, BD Pharmingen, New Jersey, USA) as a chromogen for visualization of BrdU incorporation. Forestomach tissue sections not treated with the primary antbody were used as the control. Counterstaining with Mayer's hematoxylin (Merck, Billerica, MA, USA) was used for the analysis on a light microscope.

\section{Morphometry}

Quantification of labeled $\left(\mathrm{BrdU}^{+}\right)$cells in the forestomach epithelium was performed using a computer-supported imaging system connected to a light microscope (Olympus AX70) with an objective magnification of $10 \times$. The epithelial area was calculated according to the following formula:

$$
P=p \times d^{2} / 10^{6}
$$

Where, $P$ is the surface area, $p$ is the number of grid points in the epithelium, and $d$ is the size of the square network at a magnification of $200(10 \times$ objective $)$. The number of $\mathrm{BrdU}^{+}$cells $/ \mathrm{mm}^{2}$ of epithelium $(N)$ was calculated according to the formula:

$$
N=n / P \text { : }
$$

Here, $n$ is the number of $\mathrm{BrdU}^{+}$cells on the analyzed surface, and $P$ is the analyzed surface area of epithelium. The number of proliferating $\left(\mathrm{BrdU}^{+}\right)$cells was expressed per $\mathrm{mm}^{2}$ of epithelium. 


\section{Statistical analysis}

The results are expressed as the mean \pm SD. Values were compared using the nonparametric Mann-Whitney $U$ test in the program SPSS 10 for Windows. Differences at $\mathrm{p}<0.05$ were accepted as significant.

\section{RESULTS}

The results showed the presence of proliferating $\mathrm{BrdU}$ labeled cells $\left(\mathrm{BrdU}^{+}\right)$in the basal layer of the rat forestomach epithelium of the control and BHA treated animals (Figure 1). BHA treatment ( $2 \%$ in the powdered feed, three times per week) leads to
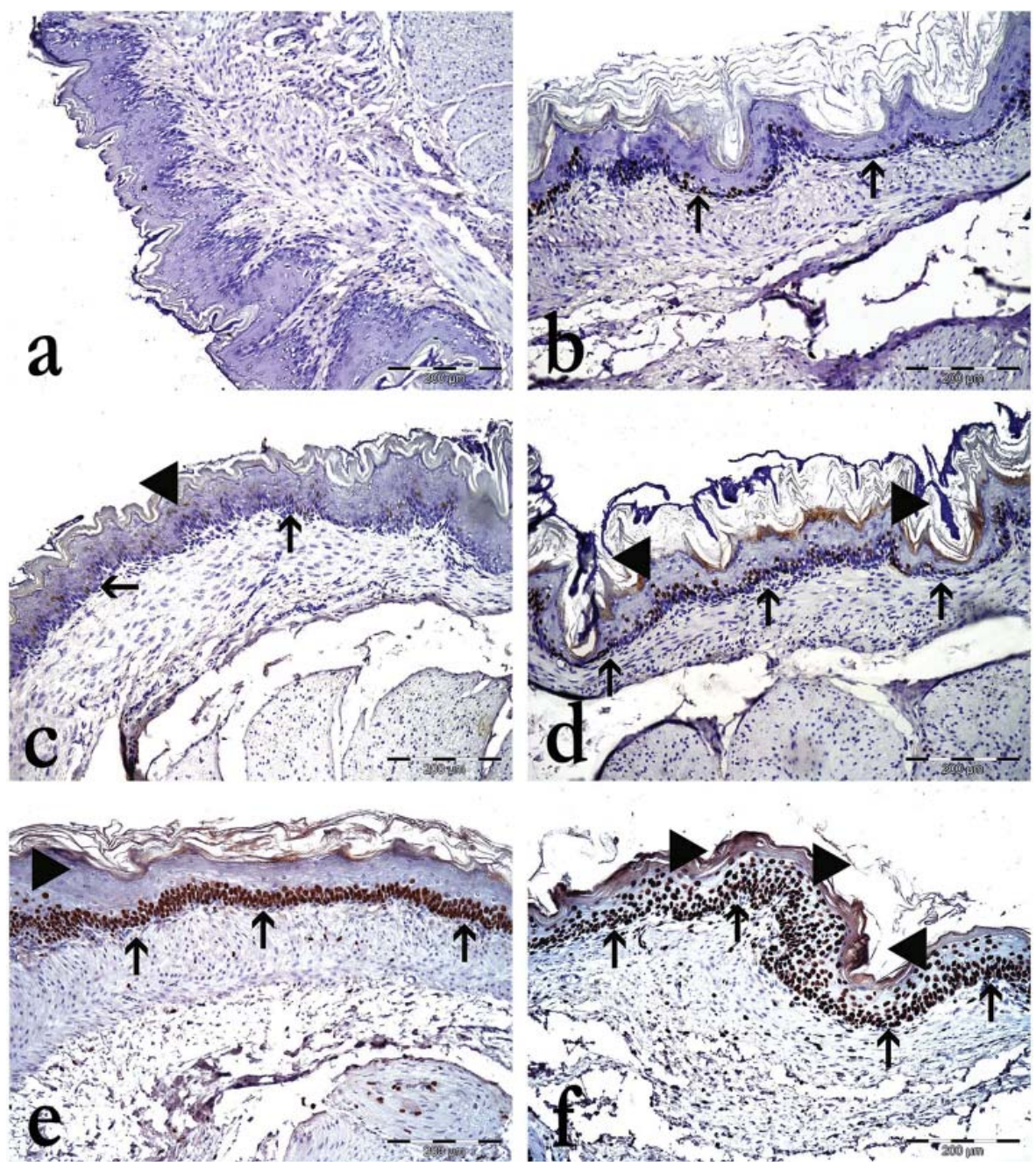

Figure 1. Immunohistochemical expression of BrdU positive cells in the rat forestomach epithelium. (A) Negative control. (B) Control rats treated with $200 \mathrm{mg}$ BrdU. (C-F) Rats treated with the same doses of BHA and different doses of BrdU for 2 days: (C) $50 \mathrm{mg}$ of BrdU, (D) $100 \mathrm{mg}$ of BrdU, (E) $200 \mathrm{mg}$ of BrdU and (F) $350 \mathrm{mg}$ of BrdU. Scale bar $200 \mu \mathrm{m}$ (right angle down). Legend: arrow - basal layer; arrow head - zone of the granulosa. 
the proliferation of cells of the basal layer of the epithelium, while the number of $\mathrm{BrdU}^{+}$cells depends on the dosage of BrdU (Figure 1C-F). BHA-treated animals which received $50 \mathrm{mg}$ of BrdU had proliferating cells mainly present in the basal layer of the epithelia and rarely in the zone of the granulosa (Figure 1C). In the treated animals, which had BrdU administered at a concentration of 100 and $200 \mathrm{mg}$ a significant increase of $\mathrm{BrdU}^{+}$cells could be seen in the basal layer of the epithelium arranged in several layers (Figure 1D-E). BHA treated animals which received $350 \mathrm{mg}$ of $\mathrm{BrdU}$ had, in addition to the presence of labeled cells in the basal layer of the epithelium, an increased presence of the $\mathrm{BrdU}^{+}$cells in the zone of the granulosa (Figure 1F).

Table 1. shows the number of $\mathrm{BrdU}^{+}$cells in the epithelium of the control and BHA treated animals in which different doses of BrdU were administered. It was shown that in animals treated with $\mathrm{BHA}$ after the application of $50 \mathrm{mg}$ of $\mathrm{BrdU}$, the number of $\mathrm{BrdU}^{+}$cells was not significantly changed in comparison to the control animals. However, application of higher doses of $\operatorname{BrdU}(100,200$ and $350 \mathrm{mg}$ ) significantly increased the number of $\mathrm{BrdU}^{+}$cells in relation to the control and the group receiving $50 \mathrm{mg}$ of BrdU. It was also shown that application of high doses of BrdU (200 and $350 \mathrm{mg}$ ) significantly increased the number of labeled cells in comparison to a dose of $100 \mathrm{mg}$ of BrdU. There were no significant changes in the number of $\mathrm{BrdU}^{+}$cells in the animals that received $200 \mathrm{mg}$ compared to animals that received $350 \mathrm{mg}$ of BrdU.

\section{DISCUSSION}

The use of BrdU for studying cell proliferation in various tissues is not of a recent date. The gut, kidney and liver were among the first analyzed tissues [13]. There are many described manners for BrdU in vivo labeling, treatment duration, methods of application and dose regimens. Therefore, the main objective of this study was to determine the optimum dose and application method of BrdU required for successful monitoring of cell proliferation in the rat forestomach for pharmacological and toxicological investigations. The rat forestomach was the target tissue considering its function as a storage organ. It serves as a holding compartment, so the tissue suffers prolonged exposure to xenobiotics [2]. In our study, butylated hydroxyanisole (BHA) was used as a proven cell proliferation agent [3]. Agents like BHA cause chronic inflammation or local irritation of the forestomach mucosa eventually leading to cell proliferation and hyperplasia [14]. In vivo labeling of DNA using BrdU should provide simple administration with minimal stress to animals and adequate dose regimens to ensure confident marking of cells.

Cantoreggi et al. (1993) applied BrdU via subcutaneous (s.c.) implantation of osmotic minipumps for proliferation studies [3]. Staszkiewicz et al. (2009) injected BrdU i.p. in mice twice daily for three consecutive days; Zhang et al. (2015) also used i.p. injection of BrdU twice a day at $2 \mathrm{~h}$ intervals over four consecutive days, whereas Ševc et al. (2015) administered BrdU dissolved in drinking water over a prolonged period of time [15-17]. While Staszkiewicz et al .(2009) and Zhang et al. (2015) concluded that 
i.p. injections of BrdU is appropriate as a biomarker of their study, Ševc et al. (2015) concluded that oral administration of BrdU does not provide accurate information about the number of proliferating cells in target tissues [15-17]. Erben et al. (2008) reported subcutaneous implementation of BrdU pellets for 3 and 7 weeks exposure, however long term exposure resulted in BrdU toxicity accompanied with decreased labeling efficiency over time, thus the precise monitoring of cell proliferation can not be achieved in this manner [18]. Weghorst et al. (1991) showed that s.c. BrdU administration for 4 days provides more accurate data of the true proliferative scenario in cell kinetic studies in contrast to the pulse-labeled approach [19]. A further increase in treatment duration decreased the number of labeled cells. Comparative use of osmotic minipumps and slow-release BrdU pellets showed that nuclear labeling was very similar with both techniques. We found that implementation of BrdU matrices subcutaneously, two days prior to sacrifice provided a slow and continuous release similar to the effect of osmotic minipumps. In contrast to osmotic minipumps administration of $\mathrm{BrdU}$ matrices is simple, the wound is minimal and sutured with one surgical stitch.

The concentration of $\mathrm{BrdU}$ has an effect on cell proliferation across a wide range of doses depending on the way of application (40-480 mg/ $\mathrm{kg}$ for i.p., and up to 2.5 $\mathrm{g} / \mathrm{kg}$ for subcutaneous application) as reported in the literature [19,20]. Our study demonstrated that s.c. application of $200 \mathrm{mg}$ of $\mathrm{BrdU}$ per animal is optimal for adequate labeling of proliferating cells in adult rats.

\section{CONCLUSIONS}

Our results showed that doses of 50 and $100 \mathrm{mg}$ of BrdU administered subcutaneously are not sufficient for adequate labeling of proliferating cells of the rat forestomach. Subcutaneous administration of $200 \mathrm{mg}$ of BrdU per animal (i.e. on average $540 \mathrm{mg}$ of $\mathrm{BrdU} / \mathrm{kgBW}$ ) is optimal for labeling proliferating cells, whereas a further increase in BrdU dose does not have an impact on the number of labeled cells. Due to the fast turnover of rat forestomach epithelium the duration of BrdU exposure of two days gave sufficient results.

Evidently, trying to standardize the dose and application method of BrdU should simplify cell proliferation studies. At least in the case of adult rats, it may be accepted that the optimum BrdU dose is $200 \mathrm{mg}$ per animal for s.c. application. These results do not provide only certain and unambiguous immunohistochemical results, but also reduces stress to animals as multiple injections are obliterated and elaborate minipumps are not required.

\section{Acknowledgements}

This work was supported by the Ministry of Education, Science and Technological Development of the Republic of Serbia (Project No. 173046) and Swedish Match AB. 


\section{Authors' contributions}

JG and DM participated in the design of the study and performed the statistical analysis. NR conceived of the study, and participated in its design and coordination and helped to draft the manuscript. MM, FJ, DD, SM, ČB and VŠA carried out the immunoassays. All authors read and approved the final manuscript.

\section{Declaration of conflicting interests}

The author(s) declared no potential conflicts of interest with respect to the research, authorship, and/or publication of this article.

\section{REFERENCES}

1. Fukushima S, Hirose M, Wanibuchi H: Squamous cell carcinoma forestomach, Rat. In: Digestive System: Monographs on Pathology of Laboratory Animals. Berlin, Germany: Springer-Verlag; 1997, 354-358.

2. Frantz JD, Betton GR, Cartwright ME, Crissman JW, Macklin AW, Maronpot RR: Proliferative lesions of the non-glandular and glandular stomach in rats GI-3. In: Guides for Toxicologic Pathology. Washington DC, USA: STP/ARP/AFIP; 1991, 1-20.

3. Cantoreggi S, Dietrich DR, Lutz WK: Induction of cell proliferation in the forestomach of F344 rats following subchronic administration of styrene 7, 8-oxide and butylated hydroxyanisole. Cancer Res 1993, 53:3505-3508.

4. Ghanayem BI, Maronpot RR, Matthews HB: Effects of sulfhydryl modulation on ethyl acrylate-induced forestomach toxicity. Toxicol Lett 1991, 55:215-221.

5. International Agency for Research on Cancer. IARC: Butylated hydroxyanisole (BHA). In: Some Naturally Occurring and Synthetic Food Components, Furocoumarins and Ultraviolet Radiation. IARC Monographs on the Evaluation of Carcinogenic Risk of Chemicals to Humans. France: International Agency for Research on Cancer; 1986, 123-159.

6. Butterworth BE: Consideration of both genotoxic and nongenotoxic mechanisms in predicting carcinogenic potential. Mutat Res 1990, 239:117-132.

7. Proctor DM, Gatto NM, Hong SJ, Allamneni KP: Mode-of-action framework for evaluating the relevance of rodent forestomach tumors in cancer risk assessment. Toxicol Sci 2007, 98:313-326.

8. King MT, Wild D, Gocke E, Eckhardt K: 5-Bromodeoxyuridine tablets with improved depot effect for analysis in vivo of sister-chromatid exchanges in bone-marrow and spermatogonial cells. Mutat Res 1982, 97:117-129.

9. Trautner TA, Swartz MN, Kornberg A: Enzymatic synthesis of deoxyribonucleic acid, x. influence of bromouracil substitutions on replication. Proc Natl Acad Sci USA 1962, 48:449-455.

10. Schmuck M, Temme T, Heinz S, Baksmeier C, Mosig A, Colomina MT, Barenys M, Fritsche E: Automatic counting and positioning of 5-bromo-2-deoxyuridine $(\mathrm{BrdU})$ positive cells in cortical layers of rat brain slices. Neurotoxicology 2014, 43:27-33.

11. Kriss JP, Revesz L: The distribution and fate of bromodeoxyuridine and bromodeoxycytidine in the mouse and rat. Cancer Res 1962, 22:254-265. 
12. Matiašová A, Ševc J, Mikeš J, Jendželovský R, Daxnerová Z, Fedoročko P: Flow cytometric determination of 5-bromo-2'-deoxyuridine pharmacokinetics in blood serum after intraperitoneal administration to rats and mice. Histochem Cell Biol 2014, 142:703-712.

13. deFazio A, Leary JA, Hedley DW, Tattersall MH: Immunohistochemical detection of proliferating cells in vivo. J Histochem Cytochem 1987, 35:571-577.

14. Kaneko M, Morimura K, Nishikawa T, Wanibuchi H, Takada N, Osugi H, Kinoshita H, Fukushima S: Different genetic alterations in rat forestomach tumors induced by genotoxic and non-genotoxic carcinogens. Carcinogenesis 2002, 23:1729-1735.

15. Staszkiewicz J, Gimble J, Cain C, Dietrich M, Burk D, Kirk-Ballard H, Gawronska-Kozak B: Flow cytometric and immunohistochemical detection of in vivo BrdU-labeled cells in mouse fat depots. Biochem Biophys Res Commun 2009, 378:539-544.

16. Zhang L, Hahong L, Zeng S, Chen L, Fang Z, Huang Q: Long-term tracing of the BrdU label-retaining cells in adult rat brain. Neurosci Lett 2015, 591:30-34.

17. Ševc J, Matiašová A, Smoleková I, Jendželovský R, Mikeš J, Tomášová L, Kútna V, Daxnerová Z, Fedoročko P: Peroral administration of 5-bromo-2-deoxyuridine in drinking water is not a reliable method for labeling proliferating S-phase cells in rats. J Pharmacol Toxicol Methods 2015, 74:33-39.

18. Erben, RG, Odörfer KI, Siebenhütter M, Weber K, Rohleder S: Histological assessment of cellular half-life in tissues in vivo. Histochem Cell Biol 2008, 130:1041-1046.

19. Weghorst CM, Henneman JR, Ward JM: Dose response of hepatic and renal DNA synthetic rates to continuous exposure of bromodeoxyuridine $(\mathrm{BrdU})$ via slow-release pellets or osmotic minipumps in male B6C3F1 mice. J Histochem Cytochem 1991, 39:177-184.

20. Hancock A, Priester C, Kidder E, Keith JR: Does 5-bromo-2'-deoxyuridine (BrdU) disrupt cell proliferation and neuronal maturation in the adult rat hippocampus in vivo? Behav Brain Res 2009, 199:218-221.

\section{PRAĆENJE ĆELIJSKE PROLIFERACIJE - OPTIMIZACIJA METODE ZA IN VIVO OBELEŽAVANJE DNK ĆELIJA ŽELUCA PACOVA}

JOKSIĆ Gordana, MIĆIĆ Mileva, FILIPOVIĆ Jelena, DRAKULIĆ Dunja, STANOJLOVIĆ Miloš, ČALIJA Bojan, VALENTA ŠOBOT Ana, DEMAJO Miroslav, NILSSON Robert

Praćenje ćelijske proliferacije je važno za istraživanja u oblasti toksikologije, patofiziologije i farmakologije. Kao pokazatelj stepena ćelijske proliferacije koristi se 5-bromo-2'-deoksiuridin koji se ugrađuje u novosintetisanu DNK ćelija u S fazi ćelijskog ciklusa. Cilj ove studije je optimizacija potkožne implantacije 5-bromo-2'deoksiuridina za kontinuirano i dugotrajno obeležavanje ćelija u deobi na modelu nežlezdanog dela želuca pacova. Ćelijska proliferacija indukovana je 3-tert-Butil-4-hidroksianizolom. 5-bromo-2'-deoksiuridin u dozama od 50 mg, 100 mg, 200 mg i 350 mg je implantiran dva dana pre žrtvovanja u formi pljosnatih cilindričih matrica u cilju utvrđivanja optimalne doze za obeležavanje ćelija u deobi. Imunohistohemijska 
analiza 5-bromo-2'-deoksiuridin in situ detekcionim kitom je korišćena za kvantifikaciju 5-bromo-2'-deoksiuridin obeleženih ćelija. Rezultati su pokazali da je za odrasle pacove optimalna doza 5-bromo-2'-deoksiuridina za potkožnu implantaciju $200 \mathrm{mg}$ po životinji. Opisani način 5-bromo-2'-deoksiuridin in vivo obeležavanja omogućava jednostavan, efikasan i pouzdan način obeležavanja ćelija sa minimalnim stresom za životinje. 